\title{
GENETIC DIVERSITY AND PARENTAGE ANALYSIS FOR DNA MARKER-BASED FOREST REPRODUCTIVE MATERIAL TRACEABILITY SYSTEM IN LITHUANIA
}

\begin{abstract}
Darius KAVALIAUSKAS, Department of Forest Sciences, Faculty of Forest Sciences and Ecology, Vytautas Magnus University, K. Donelaičio g. 58, LT-44248 Kaunas, Lithuania, darius.kavaliauskas@ vdu.lt (corresponding author)

Barbara FUSSI, Bavarian Office for Forest Genetics, Forstamtsplatz 1, 83317 Teisendorf, Germany, barbara.fussi@awg.bayern.de Monika SIRGE்DIENE், Department of Forest Sciences, Faculty of Forest Sciences and Ecology, Vytautas Magnus University, K. Donelaičio g. 58, LT-44248 Kaunas, Lithuania, monika.sirgediene@ vdu.lt

Rūta KEMBRYTÉ, Department of Forest Sciences, Faculty of Forest Sciences and Ecology, Vytautas Magnus University, K. Donelaičio g. 58, LT-44248 Kaunas, Lithuania, ruta.kembryte@ vdu.lt

Darius DANUSEVIČIUS, Department of Forest Sciences, Faculty of Forest Sciences and Ecology, Vytautas Magnus University, K. Donelaičio g. 58, LT-44248 Kaunas, Lithuania, darius.danusevicius@ vdu.1t
\end{abstract}

Scots pine is economically and ecologically important forest tree species in Lithuania. According to the Regulation of Forest Planting and Restoration of Lithuania (2018) and the Regulations on Forest Reproductive Material (FRM) (2017) forests must be planted and replanted with the target tree species, using high quality seeds and seedlings from a given provenance. EU Council Directive $(1999 / 105 / E C)$ indicates that EU Member States are responsible for the regulation, requirements and implementation of FRM quality and traceability system. The existing FRM control system in Lithuania is based on the control actions of the supporting documents regarding the origin of FRM. However, this FRM traceability system is limited and, in some cases, cannot ensure that FRM used for reforestation/afforestation originates from the declared place of origin or belongs to a certain seed or plant lot. In this study we aimed to assess and compare genetic diversity of scots pine seed orchard clones with seeds, and to test DNA based parentage analysis methods with Jonava scots pine seed orchard clones and seeds. Up to now DNA markers based FRM traceability system in Lithuania has not been tested and implemented. Thus, our first results based on 12 nuclear microsatellite markers indicated that genetic diversity among Jonava seed orchard clones and collected seeds were moderately high and comparable with other studies on scots pine in Europe. The test of the maternity analysis software CERVUS has showed very positive results in maternity assignments. Therefore, selected microsatellite markers in combination with accurate sampling design and specific DNA analysis methods should be improved and can be used for FRM traceability system based on DNA "fingerprints".

This work is supported by the Project. No. 09.3.3-LMT-K-712-19-0007.

Keywords: FRM, traceability system, maternity analysis, DNA, Scots pine, (Pinus sylvestris L.), seed orchard

\section{INTRODUCTION}

Scots pine (Pinus sylvestris L.) is the most common, economically and ecologically important forest tree species in Europe. In Lithuania, Scots pine occupies more than 34.5\% of the forest land (Lithuania State Forest Service, 2019). According to the national Regulation on Forest Reproductive Material (2017), forests must be established with the target tree species, with reproductive material complying to the quality and origin requirements set in the regulations. Forest reproductive material must be of know origin and for Scot pine collected in approved stands for seed collection or seed orchards. Forest reproductive material produced according to these requirements will ensure that newly planted forests will be well adapted to local environments. Securing adaptation becomes very important task under gradually increasing environmental pressure due to climate change.

Lithuania has implemented the EU Council Directive 1999/105/EC on the marketing of FRM, which underlines that Member States have to use locally best genetically and phenotypically suited FRM, which have to ensure adaptability, resilience, productivity and diversity of forests at specific local conditions. Therefore, origin of the FRM, which are planted in Lithuania forests must be known and must be selected according to genetic and phenotypic features. According to the General Declaration of the Third Ministerial Conference on the Protection of Forest in Europe in Lisbon, for reforestation and afforestation, origins of native species and local provenances that are well adapted to site conditions should be preferred. In addition, EU Council Directive (1999/105/EC) indicates that EU Member States are responsible and must agree on the regulation, requirements and implementation of FRM quality and traceability system. The Member States should establish lists and maps of regions of provenance specifying, where known, the origin of basic material, in

Copyright (C) 2021 The Authors. Published by Vytautas Magnus University. This is an open-access article distributed under the terms of the Creative Commons Attribution License (CC BY 4.0), which permits unrestricted use, distribution, and reproduction in any medium, provided the original author and source are credited. 
addition national register of seed orchard, seed stands, genetic reserves should be prepared. Hence, controlling institution in each Member State has to ensure that, in addition to possessing the required phenotypic and genetic quality, reproductive material which is intended for marketing or which is placed on the market is properly identified from collection to delivery to the end user. FRM of false origin may bring economical loss to customers and reduce adaptability of native populations via genetic pollution via pollen flow and seed. However, existing FRM control system in Lithuania is based only on control actions, trust and supporting documents/certificates of origin. In addition, Lithuania has committed to implement similar trust and documents based FRM control system by joining the Organization for Economic Cooperation and Development in 2018 (OECD, 2010). However, existing FRM traceability control system in Lithuania is limited and cannot ensure that the seeds and seedlings used for reforestation and afforestation originates from documented/declared place of origin or belongs to the same seed or plant lot. Therefore, is increasing risk that seed and seedling imported and planted from unknown/unchecked source of origin will be not suitable and adapted for local growth conditions, specifically in the light of climate change. As a result, Lithuania may face economic and ecological losses in the future due to reduced forest growth, lack of tree adaptation or even dieback of populations. However, an effective FRM traceability control system based on DNA markers (species-specific DNA markers - microsatellites) could ensure the highest accuracy in tracing FRM origin using reference seed lot samples and DNA "fingerprints" collected from seed stands and seed orchards.

Therefore, existing forest genetic research infrastructure in Lithuania and Good Practice Examples in Europe (e.g., Germany (Konnert and Behm, 2006, Degen et al., 2010, Finkeldey et al., 2010), Slovenia (Westergren et al., 2012), etc.) provide opportunities to implement FRM traceability system based on DNA markers in Lithuania for economically most important forest tree species - Scots pine. In addition, implementation of FRM traceability system in Lithuania based on DNA markers is an important goal enabling better implementation of EU and OECD requirements, which will ensure more sustainable and productive forest growth in the future, which is vital for seeking goals of the EU Green Deal.

The main aims of the study were (i) to compare genetic diversity between of Scots pine seed orchard clones and their progeny, (ii) to test DNA analysis methods (parentage analysis) for DNA based FRM traceability system implementation based on genotyping a Scots pine and its progeny in Lithuania. Up to now DNA markers based FRM traceability system in Lithuania has not been tested and implemented.

\section{MATERIAL AND METHODS}

We genotyped 21 clone with 10 to 20 open-pollinated progeny per clone from Jonava seed orchard. The OP seeds were germinated and DNA was extracted from the needles. In total, 415 samples were used for DNA extraction and further analysis. Total genomic DNA was extracted from frozen needles according to an adjusted ATMAB DNA extraction method (Dumolin et al., 1995). In total 415 samples were used for DNA analysis with 12 nuclear microsatellite markers (nSSR: psyl2; psyl16; psyl18; psyl25; psyl42; psyl44; psyl57 (Sebastiani et al., 2012); SPAC7.14; SPAC11.4; SPAC12.5 (Soranzo et al., 1998); PtTX4001; PtTX4011 (Auckland et al., 2002)). Polymerase chain reaction and multiplexing was done according to Danusevičius et al. (2016). Amplified PCR products were separated by capillary electrophoresis using an ABI PRISMTM 310 Genetic Analyzer (Applied Biosystems, Foster City, California, USA)). GeneScan-500 LIZ (Applied Biosystems) was used as an internal size standard. Allele sizing was performed on a binset by using the program GeneMapper (Applied Biosystems version 4.0, Foster City, California, USA).

Genetic diversity parameters were calculated for the two groups (21 clone and 394 seeds): number of different alleles (Na), number of effective alleles ( $\mathrm{Ne}$ ), observed (Ho)/expected (He)/unbiased (uHe)expected heterozygosity, and fixation index (F)) based on 12 microsatellite loci using the GenAlEx 6.5 software (Peakall und Smouse, 2012). Allelic richness (Ar) was estimated with the FSTAT 2.9.3. software (Goudet, 2001), the lowest number of samples (21) was used for rarefaction. The software estimates allelic richness per locus, sample, and samples overall. Allelic richness is a measure of the number of alleles independent of sample size, thus allowing for comparison between different sample sizes among generations. Discriminant analysis of principal components (DAPC) was used to examine the clustering of individuals ( $\mathrm{R}$ package adegent 2.0.0 (Jombart, 2015; Jombart and Collins, 2015). To reliability of progeny assignment to particular seed orchard based on 12 nuclear microsatellite loci, we run maternity assignment analysis with the Jonava seed orchard progeny by using program CERVUS version 3.0.7 (Kalinowski et al., 2007). In this analysis, we assigned the progeny to the 21 clone from the Jonava seed orchard. For the CERVUS run, the parameters were set at the default values except for those noted below. Each Cervus run consisted of completing an allele frequency analysis, followed by a simulation of maternity analysis where the number of potential mothers was set to 21 , with a proportion of mothers sampled set to $95 \%$. This parameter allows the software to consider the possibility that the actual mother was not genotyped, which was assumed to be rarely possible. Proportion of typed loci was set to $94 \%$ as the allele frequency analysis has estimated. A minimum of 10 typed loci were required for progeny to be analysed for maternity, and the number of progenies simulated was set to 100000. The proportion of loci mistyped allows for errors in genotyping and was tested with different thresholds: $0.001,0.01,0.05$ and 0.1 .

\section{RESULTS}

\section{Genetic diversity}

There were no significant differences in the genetic diversity estimates among the clones of the Jonava seed (Table 1). The mean number of alleles (Na) ranged from 7.08 (JSP_Clones) to 13.83 (JSP_Seed) with an average of 
$\mathrm{Na}=10.46$. Mean number of effective alleles (Ne) varied from 4.28 (JSP_Clones) to 5.09 (JSP_Seed) with an overall average of $\mathrm{Ne}=4.69$. Expected heterozygosity $(\mathrm{He})$ was moderate (mean $\mathrm{He}=0.534)$, allelic richness (Ar) varied from 7.08 (JSP_Clones) to 7.40 (JSP_Seed) with an overall average of Ar $=7.24$. In total, 81 private alleles were present only among JSP_Seed group individuals. Mean observed heterozygosity $($ Ho $=0.512)$ was slightly lower than mean expected heterozygosity $(\mathrm{He}=0.534)$. Values of expected heterozygosity $(\mathrm{He})$ and unbiased heterozygosity ( $\mathrm{uHe}$ ) averaged 0.534 and 0.540 , respectively. The fixation index (F) based on 12 microsatellite loci was higher in JSP_Seed $(F=0.170)($ Table 1$)$.

Table 1. The genetic diversity parameters with standard errors (SE) of the two scots pine generations: clones and seed from Jonava seed orchard estimated based on 12 nSSR loci.

\begin{tabular}{|c|c|c|c|c|c|c|c|c|c|}
\hline Generation & $N$ & $N a$ & $N e$ & $A r$ & $N p$ & $H o$ & $H e$ & $u H e$ & $F$ \\
\hline JSO_Clones & 21 & 7.08 & 4.28 & 7.08 & 0 & 0.560 & 0.518 & 0.531 & -0.069 \\
\hline SE & - & 1.676 & 1.218 & 1.60 & - & 0.113 & 0.104 & 0.107 & 0.034 \\
\hline JSP_Seed & 394 & 13.83 & 5.09 & 7.40 & 81 & 0.464 & 0.549 & 0.550 & 0.170 \\
\hline SE & - & 2.912 & 1.553 & 1.54 & - & 0.090 & 0.104 & 0.104 & 0.046 \\
\hline Mean & - & 10.46 & 4.69 & 7.24 & 40.5 & 0.512 & 0.534 & 0.540 & 0.050 \\
\hline SE & - & 1.788 & 0.969 & 1.14 & - & 0.071 & 0.072 & 0.073 & 0.037 \\
\hline
\end{tabular}

* N - sample size; $\mathrm{Na}$ - mean no. of different alleles; $\mathrm{Ne}$ - mean no. of effective alleles; Ar - allelic richness (based on min. sample size of 21 individual); $\mathrm{Np}$ - no. of private alleles; Ho - observed heterozygosity; He - expected heterozygosity; uHe - unbiased expected heterozygosity; $\mathrm{F}$ - fixation index.

Discriminant analysis of Principal Components (DAPC) analysis revealed two groups of individuals JSP_Clones and JSP_Seed with overlapping distribution of allele frequencies in all the loci, which indicates similarity of the two groups and confirms the origin of the seeds (Fig. 1).

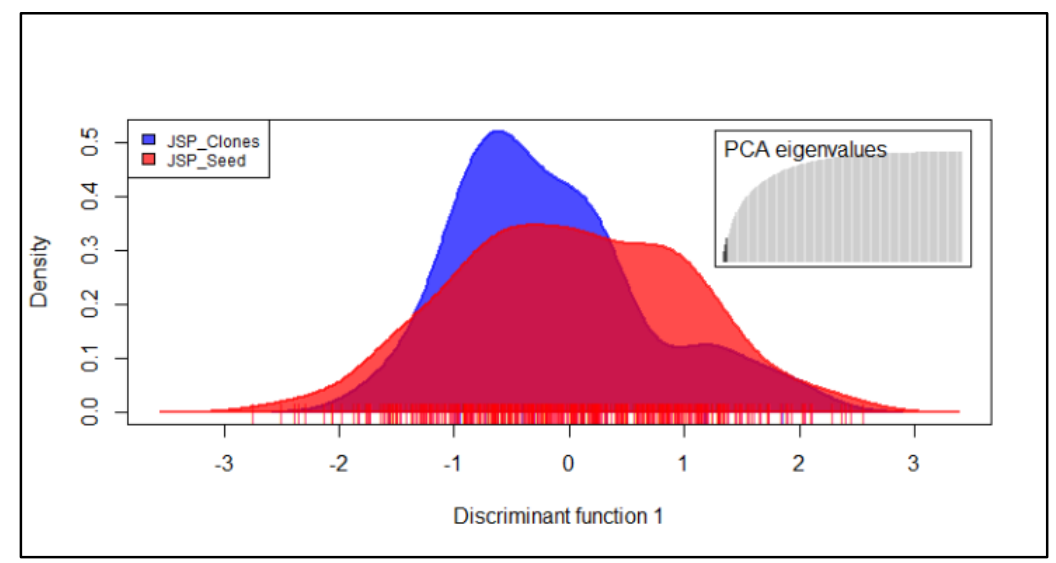

Figure 1. Discriminant analysis of Principal Components (DAPC) (R package adegent).

Moreover, population assignment analysis suggested existence of one genetic cluster, where both groups JSP_Clones and JSP_Seed overlap, which approves a clear seed assignment (orange cloud) to seed orchard clones (red cloud) (Figure 2).

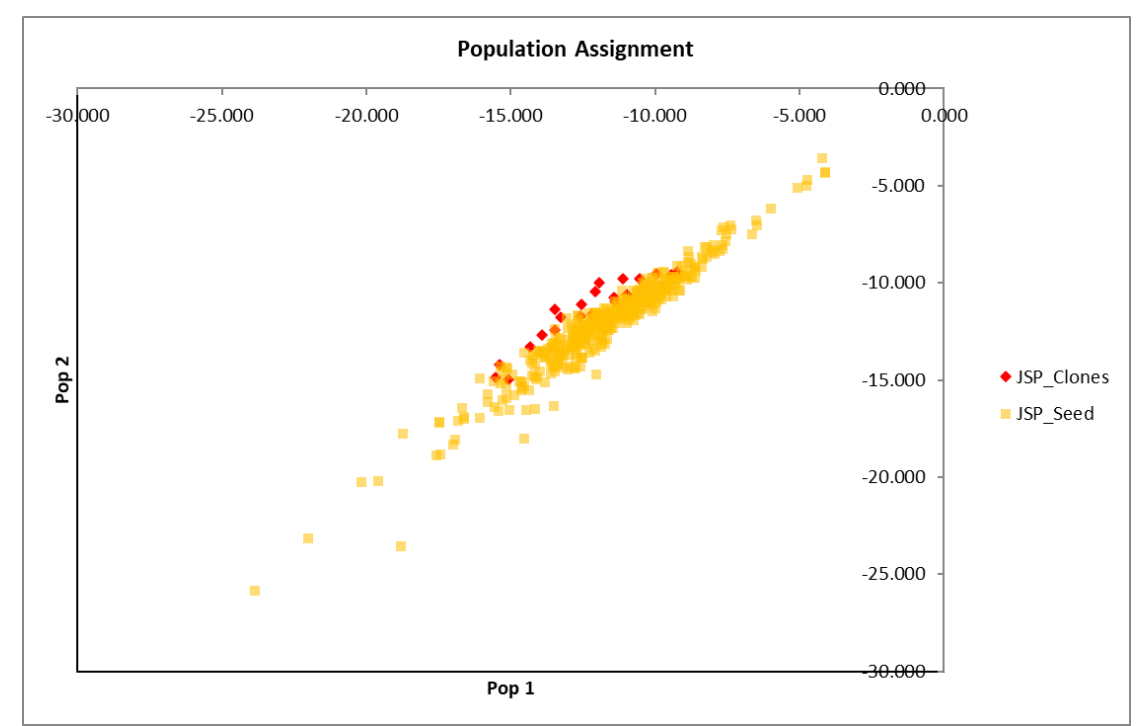

Figure 2. Assignment plot showing clustering of the two sampled groups JSP_Clones and JSP_Seed (soft. GenAlEx 6.5). 


\section{Maternity analysis}

The software CERVUS used in our data analysis assigned maternity to 341 out of 394 progenies from Jonava seed orchard with the proportion of loci mistyped 0.001 . Of the 394 progenies 24 were removed from further analysis with CERVUS, because they were typed at fewer than 10 microsatellite loci. Thus, from remaining 370 seeds mothers were assigned correctly for 341 (92\%) of progenies at strict delta confidence level using 12 microsatellite loci. Only for 24 of the 370 progeny the algorithm failed to identify the correct mother clones (Tab.2). Inspection of the 14 seed that were not assigned at the $95 \%$ confidence level revealed clear mismatches between the genotypes of known mothers and their progenies. This indicates either an error in genotyping or in recording which progeny came from which mother rather than an error due strictly to insufficient genetic variation at these 12 microsatellite loci. Further results with different proportion of loci mistyped are given in Table 2.

Table 2. Cervus maternity analysis: Mother alone (all offspring*)

\begin{tabular}{|c|c|c|c|c|c|c|c|}
\hline $\begin{array}{l}\text { Minimum } \\
\text { typed loci }\end{array}$ & $\begin{array}{c}\text { Prop. Loci } \\
\text { mistyped }\end{array}$ & $\begin{array}{c}\text { Total no. of } \\
\text { offspring }\end{array}$ & $\begin{array}{c}\text { Total no. of } \\
\text { offspring } \\
\text { tested }\end{array}$ & $\begin{array}{c}\text { Assignments } \\
\text { observed } \\
\text { (Delta 95\%) }\end{array}$ & $\begin{array}{c}\text { Assignment } \\
\text { Rate \% (Delta } \\
95 \%)\end{array}$ & $\begin{array}{c}\text { Assignments } \\
\text { observed } \\
\text { (Delta 80\%) }\end{array}$ & $\begin{array}{c}\text { Assignment } \\
\text { Rate \% (Delta } \\
80 \%)\end{array}$ \\
\hline 10 & 0.001 & 394 & 370 & 341 & 92 & 341 & 92 \\
\hline 10 & 0.01 & 394 & 370 & 352 & 95 & 352 & 95 \\
\hline 10 & 0.05 & 394 & 370 & 339 & 92 & 361 & 98 \\
\hline 10 & 0.1 & 394 & 370 & 301 & 81 & 363 & 98 \\
\hline
\end{tabular}

*Number of offspring (total): 394; Number of offspring tested (typed at 10 or more loci): 370; Not tested (typed at fewer than 10 loci): 24 (were excluded from analysis because they were typed at fewer than 10 loci).

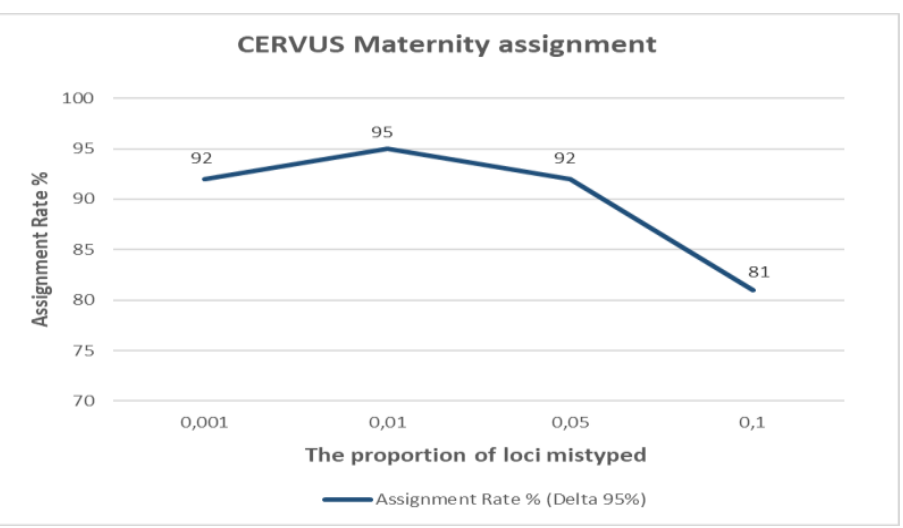

Figure 3. The percentage of Jonava seed orchard progenies statistically significantly assigned to Jonava seed orchard clones depending on the proportion of the mistyped loci (X axis) based on the the Maximum Likelihood analysis in CERVUS maternity assignment. The solid line indicates an analysis scenario that allows progeny genotypes to have unknown alleles at up to two loci. The threshold of $70 \%$ of correctly assigned individuals may be considered as a safe lower margin for positive assignment of a seed lot to a particular seed orchard.

Overall, the results of the CERVUS analysis showed that when variation in proportion of loci mistyped from 0.001 to 0.1 , led to the average percentage of correctly assigned offspring from 81 to $95 \%$ at Delta $95 \%$ significance level (Tab. 2 ). The lowest assignment percentage of $81 \%$ was obtained by accepting the possibility of genotyping errors with $10 \%$ (expressed as a ratio of 0.1 ) and the highest assignment percentage of $95 \%$ was obtained by accepting the possibility of genotyping errors with $1 \%$ (expressed as a ratio of 0.01) (Tab. 2 and Fig. 3).

\section{DISCUSSION AND CONCLUSIONS}

The genetic diversity parameters such as mean number of alleles $(\mathrm{Na})$, mean number of effective alleles $(\mathrm{Ne})$, allelic richness (Ar) and heterozygosity were comparable with other studies for Scots pine in Europe (e.g. Garcia-Gil et al. 2009; Belletti et al., 2012, Garcia-Gil et al. 2015, Danusevičius et al., 2016 etc.). Allelic diversity parameters (Na and $\mathrm{Ne}$ ) were higher in the progeny because of different sample size, but allelic richness (Ar) and unbiased expected heterozygosity $(\mathrm{uHe})$ were similar between the progeny and the parental clones from Jonava seed orchard. However, observed heterozygosity (Ho) was markedly lower and predicted inbreeding (Fis) higher in seed orchard crop. Namely, these two indexes (Ho and Fis) are least dependent on the sample size and provide a good estimate of genetic diversity between the two generations (e.g. Danusevicius et al. 2016). The seed orchard clones represent population of high fitness, whereas progeny may contain some inbreeding owing to mating among related clones. Therefore, family members (half sibs) should be placed as clones into single orchard with caution. This finding indicates that number of seed orchard clones is an important tissue to be optimised following the recommendations from EUFORGEN, that seed orchards should be established and managed to promote genetic diversity and genetic mixing to increase the adaptability of future forests trough seed production (Gömöry et al. 2021). Furthermore, the genetic and genotypic diversity of seed crops can be 
compared with the natural populations if the number of unrelated clones is large enough to represent the gene pools of the populations of origin, then genetic diversity of replanted forests can be increased.

As a second step the discriminant analysis of Principal Components (DAPC) analysis and population assignment analysis clearly displayed that the two groups of seed orchard clones and seed have overlapping distribution and the results are supporting the origin of the seeds. Our findings showed that 12 microsatellites would be sufficient for highly reliable group-wise assignment of seeds to their seed orchard of origin and are in agreement with other studies on the FRM traceability of different tree species, e.g.: Abies alba (Cremer et al. 2003), Quercus robur (Degen et al. 2010), Fagus sylvatica (Hasenkamp et al. 2011), etc.

As a final step, the analysis of maternity was tested and optimal parameters for analysis based on 12 DNA marker were discussed. There are several issues related to nSSR genotyping errors and cost-effective use of the results for maternity analysis. In our study we allowed in any two out of the 12 loci to have missing data in the genotypes, especially knowing that the result of statistical assignment does not differ significantly from the analysis with strictly complete 12 locus genotypes (results not shown). CERVUS analysis showed that even with $10 \%$ of the proportion of loci mistyped (0.1 X axis value in Fig. 3) 81\% of Jonava SP progeny were statistically significantly assigned to Jonava seed orchard clones, which indicates the high resolution of our DNA marker system for maternity analysis. The criteria for assignment LOD and Delta based on DNA markers were similar, indicating that there is only one most probable maternal clone from which seeds were collected. The software CERVUS have successfully assigned most of the seeds to the right clones within Jonava seed orchard with high significance (95\%). The only exceptions were a few individuals (5\%) of the total seed number, which were not assigned. This result indicates high efficiency of these 12 DNA microsatellite loci for identification the origin/maternity of Scots pine seeds. Similar analysis was performed on Pinus taeda (L.) seed orchard by Grattapaglia et al. (2014). Wang et al. (2010) have used similar approach to study Scots pine seed orchard crop, in order to develop the appropriate parentage assignment techniques for breading without breading (BWB) and the results were promising, while up to $97 \%$ of the seeds generated by mating among the seed orchard clones were correctly assigned to a parent-pair.

In conclusion, our results are in agreement with other studies and indicate that the methodology presented here is successful in determining maternity with up to $95 \%$ success by using 12 microsatellite loci at $>95 \%$ delta confidence level, with the only error due to inaccurate genotyping, and no information about paternal genotypes. Future use of the methodology presented here has the potential to allow for Scots pine FRM from seed orchards traceability implementation via the clones DNA "fingerprinting" and assignation of maternity using these 12 microsatellite loci. Genetic diversity comparison between parental and progeny generations returned higher inbreeding in the progeny generation, which indicate that related individuals should be used as seed orchard clones with caution.

Acknowledgments. This project has received funding from European Social Fund (Project. No. 09.3.3-LMT-K-712-19-0007) under grant agreement with the Research Council of Lithuania (LMTLT).

\section{REFERENCES}

1. Auckland L. D., Bui T., Zhou Y., Shepherd M., Williams C. G. 2002. Conifer microsatellite handbook. Texas A\&M University, College Station TX, $57 \mathrm{p}$.

2. Belletti, P., Ferrazzini, D., Piotti, A., Monteleone, I., Ducci, F. 2012. Genetic variation and divergence in Scots pine (Pinus sylvestris L.) within its natural range in Italy. European Journal of Forest Research, Vol. 131(4), pp. 1127-1138. https://doi.org/10.1007/s10342-011-0584-3

3. Cremer, E., Liepelt, S., Ziegenhagen, B., Hussendorfer, E. 2003. Microsatellite and isozyme markers for seed source identification in silver fir. Forest Genetics, Vol. 10(3), pp. 165-170.

4. Danusevicius, D., Kerpauskaite, V., Kavaliauskas, D., Fussi, B., Konnert, M., Baliuckas, V. 2016. The effect of tending and commercial thinning on the genetic diversity of Scots pine stands. European Journal of Forest Research, Vol. 135(6), pp. 11591174. https://doi.org/10.1007/s10342-016-1002-7

5. Degen, B., Höltken, A., Rogge, M. 2010. Use of DNA-fingerprints to control the origin of forest reproductive material. Silvae Genetica, Vol. 59(6), pp. 268-273. https://doi.org/10.1515/sg-2010-0038

6. Dumolin S., Demesure B., Petit R. J. 1995. Inheritance of chloroplast and mitochondrial genomes in pedunculated oak investigated with an efficient PCR method. Theoretical and Applied Genetic, Vol. 91, pp. 1253-1256. https://doi.org/10.1007/BF00220937

7. EU Council Directive 1999/105/EC. 1999. Available at https://eur-lex.europa.eu/legal-content/EN/ALL/?uri=CELEX\%3 A31999L0105 (accessed on 24/05/2021)

8. Finkeldey, R., Leinemann, L., Gailing, O. 2010. Molecular genetic tools to infer the origin of forest plants and wood. Applied Microbiology and Biotechnology, Vol. 85(5), pp. 1251-1258. https://doi.org/10.1007/s00253-009-2328-6

9. García-Gil, M. R., Floran, V., Östlund, L., Gull, B. A. 2015. Genetic diversity and inbreeding in natural and managed populations of Scots pine. Tree Genetics \& Genomes, Vol. 11(2), 28. https://doi.org/10.1007/s11295-015-0850-5

10. García-Gil, M. R., Olivier, F., Kamruzzahan, S., Waldmann, P. 2009. Joint analysis of spatial genetic structure and inbreeding in a managed population of Scots pine. Heredity, Vol. 103(1), pp. 90-96. https://doi.org/10.1038/hdy.2009.33

11. Gömöry, D., Himanen, K., Tollefsrud, M., et al. 2021. Genetic aspects in production and use of forest reproductive material: Collecting scientific evidence to support the development of guidelines and decision support tools. European Forest Genetic Resources Programme (EUFORGEN), European Forest Institute, 216 p.

12. Goudet, J. 2001. FSTAT, a program to estimate and test gene diversities and fixation indices (version 2.9. 3). 
13. Grattapaglia, D., do Amaral Diener, P. S., Dos Santos, G. A. 2014. Performance of microsatellites for parentage assignment following mass controlled pollination in a clonal seed orchard of loblolly pine (Pinus taeda L.). Tree Genetics \& Genomes, Vol. 10(6), pp. 1631-1643. https://doi.org/10.1007/s11295-014-0784-3

14. Hasenkamp, N., Ziegenhagen, B., Mengel, C., Schulze, L., Schmitt, H. P., Liepelt, S. 2011. Towards a DNA marker assisted seed source identification: a pilot study in European beech (Fagus sylvatica L.). European Journal of Forest Research, Vol. 130(4), pp. 513-519. https://doi.org/10.1007/s10342-010-0439-3

15. Jombart, T. 2015. An introduction to adegent 2.0. 0. R-tutorial, Imperial College London Google Scholar.

16. Jombart, T., Collins, C. 2015. A tutorial for discriminant analysis of principal components (DAPC) using adegenet 2.0. 0. Imp Coll London-MRC Cent Outbreak Anal Model, 43 p.

17. Kalinowski, S. T., Taper, M. L., Marshall, T. C. 2007. Revising how the computer program CERVUS accommodates genotyping error increases success in paternity assignment. Molecular Ecology 16: 1099-1106. https://doi.org/10.1111/j.1365$\underline{294 X .2007 .03089 . x}$

18. Kamvar, Z. N., Tabima, J. F., Grünwald, N. J. 2014. Poppr: an R package for genetic analysis of populations with clonal, partially clonal, and/or sexual reproduction. PeerJ, Vol. 2, e281. https://doi.org/10.7717/peerj.281

19. Konnert, M., Behm, A., für forstliche Saat-und, B. A., Teisendorf, P. 2006. Proof of identity of forest reproductive material based on reference samples. Mitteilungen der Bundesforschungsanstalt. $r$ Forst-u. Holzwirtschaft (BFH), Vol. 221, pp. 61-71.

20. Lithuania State Forest Service. 2019. Lietuvos miškų ūkio statistika 2019. https://doi.org/10.1055/s-0036-1595620

21. Miško atkūrimo ir ịveisimo nuostatos. 2018. LRAM ịsakymas: 200804 14, Nr. D1-199. Available at https://e-seimas.lrs.lt/ portal/legalAct/lt/TAD/TAIS.318353/asr (accessed on 24/05/2021)

22. Miško dauginamosios medžiagos nuostatos. 2017. LRAM įsakymas: 200310 29, Nr. 521. Available at https://e-seimas.lrs.lt/ legalAct/lt/TAD/TAIS.221397/asr (accessed on 24/05/2021)

23. OECD. 2010. Scheme for the Certification of Forest Reproductive Material Moving in International Trade. Available at https://www.oecd.org/agriculture/forest/documents/forest-scheme-rules-and-regulations.pdf (accessed on 24/06/2021)

24. Peakall, R., Smouse P. E. 2012. GenAlEx 6.5: genetic analysis in Excel. Population genetic software for teaching and research-an update. Bioinformatics, Vol. 28, pp. 2537-2539. https://doi.org/10.1093/bioinformatics/bts460

25. Sebastiani F., Pinzauti F., Kujala S. T., González-Martínez S. C., Vendramin G. G. 2012. Novel polymorphic nuclear microsatellite markers for Pinus sylvestris L. Conservation Genetics Resources, Vol. 4(2), pp. 231-234. https://doi.org/10.1007/s12686-0119513-5

26. Soranzo N., Provan J., Powell W. 1998. Characterization of microsatellite loci in Pinus sylvestris L. Molecular Ecology, Vol. 7 , pp. $1260-1261$.

27. Wang, X. R., Torimaru, T., Lindgren, D., Fries, A. 2010. Marker-based parentage analysis facilitates low input 'breeding without breeding'strategies for forest trees. Tree Genetics \& Genomes, Vol. 6(2), pp. 227-235. https://doi.org/10.1007/s11295-009-0243-8

28. Westergren, M., Jarni, K., Brus, R., Kraigher, H. 2012. Implications for the use of forest reproductive material of common ash (Fraxinus excelsior L.) in Slovenia based on the analysis of nuclear microsatellites. Šumarski list, Vol. 136(5-6), pp. 263-270. 